\title{
An issue honoring Ian S. E. Carmichael
}

\author{
Mark S. Ghiorso • Gordon Moore • \\ Paul J. Wallace
}

Published online: 22 August 2013

(C) Springer-Verlag Berlin Heidelberg 2013

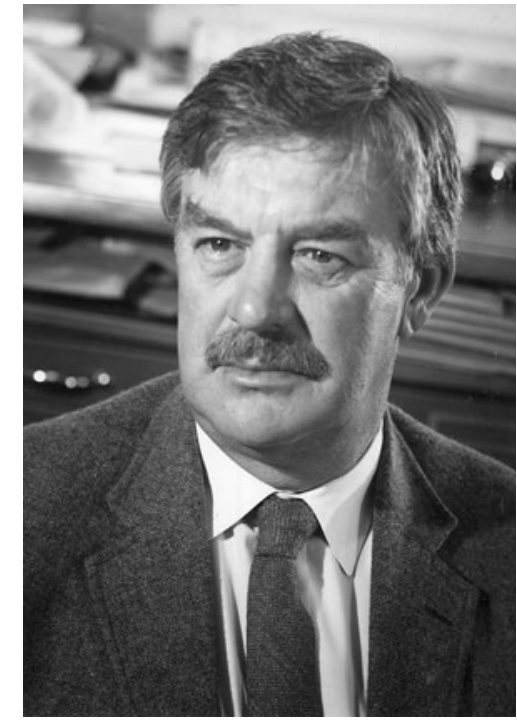

Fig. 1 Portrait of Ian Carmichael, taken by Joachim Hampel in 1986 for the occasion of Ian's receipt of the Bowen Award from the VGP section of the American Geophysical Union

Ian Stuart Edward Carmichael (b. 1930-d. 2011; Fig. 1), F.R.S., was one of the pre-eminent petrologists of the last century. He was the executive editor of Contributions to

M. S. Ghiorso $(\bowtie)$

OFM Research, 7336 24th Ave. NE, Seattle, WA 98115, USA

e-mail: ghiorso@ofm-research.org

G. Moore

Earth and Environmental Sciences, University of Michigan,

2534 C.C. Little Building, 1100 North University Ave,

Ann Arbor, MI 48109, USA

P. J. Wallace

Geological Sciences, University of Oregon, Eugene,

OR 97403, USA
Mineralogy and Petrology from 1973 through 1990, during which time he guided the journal to international prominence. The papers that appear in this special issue are dedicated to his enormously creative research career, the impact he made in transforming the field of igneous petrology into a quantitative discipline, and the unparalleled intellectual generosity he showed toward his students and academic colleagues.

Since his passing, there have been many excellent biographical sketches of Ian's life and critiques of his research contributions (e.g., Lange, R., 2012, Ian S. E. Carmichael, 1930-2011, Eos Trans. AGU, 93, 68). Our remarks here are not intended to duplicate these. What we wish to call attention to in this preface is the enormous impact that Ian has had through his academic legacy. Throughout his life, Ian devoted himself unhesitatingly to his students, to his academic associates, and to his University. He gave freely of ideas, many of which shaped the careers and reputations of the recipients, yet never demanded recognition of these gifts. If you asked Ian why he was so successful, he would merely say that he was lucky that he had such talented students. This was in fact true, but minimized the enormous impact he had on his student's lives and abilities. He had a remarkable ability to forge his students into inquisitive, precise, and productive scientists. Ian was a university administrator of unparalleled achievement because he believed in service and the notion that a privileged position in society demands a responsibility to others. He was gregarious, funny, engaging, and dominant, both intellectually and physically. Yet, he was kind and gracious, and cared deeply for the success and achievements of those around him. Ian's academic legacy is inspiring. Over his long career, he had over $30 \mathrm{Ph} . \mathrm{D}$. students, and these students in turn have careers that are influencing a second 


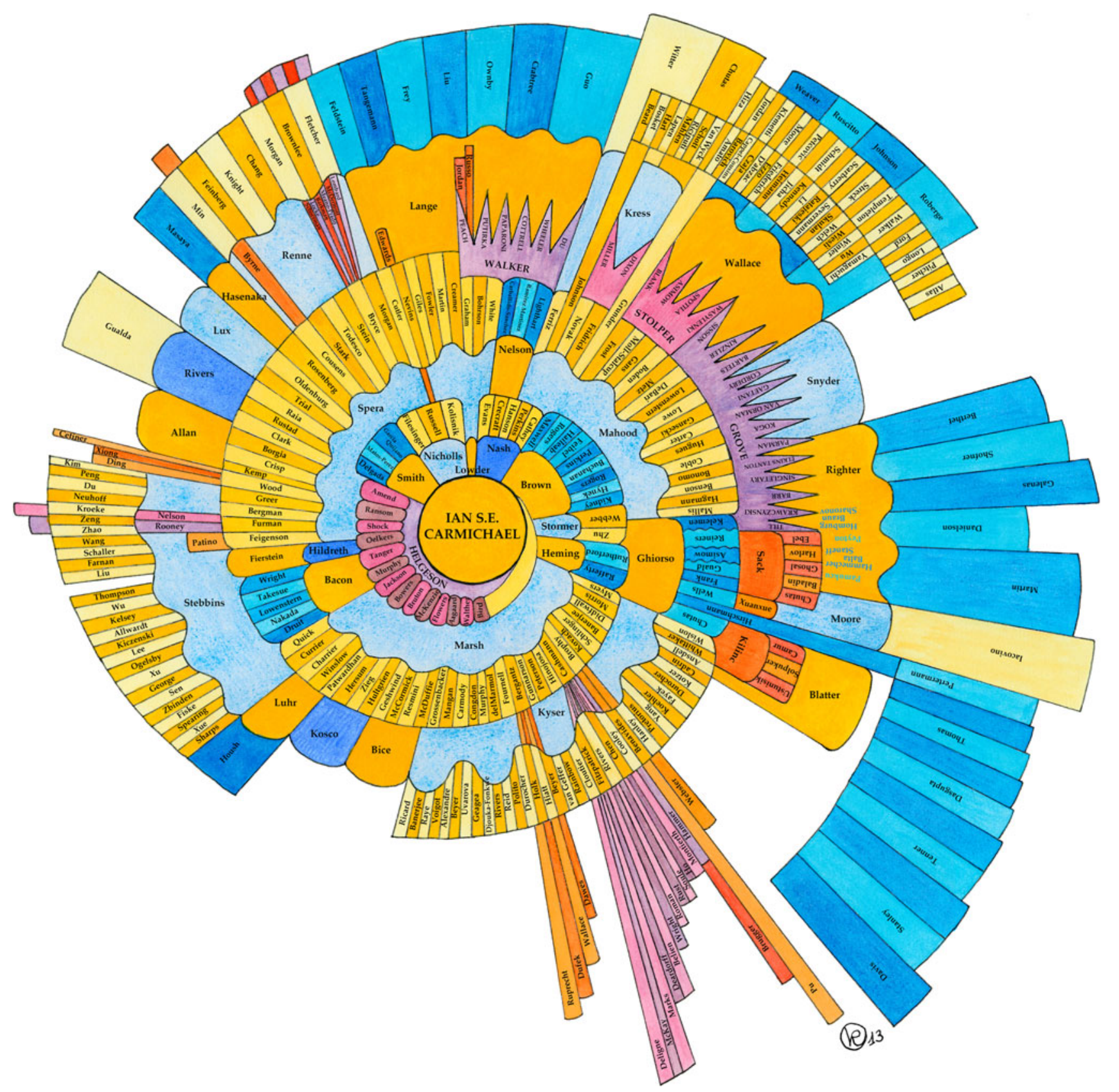

Fig. 2 Artistic rendering of the academic legacy of Ian Carmichael. Ian's Ph.D. students are labeled with "horizontal" type and spiral out chronologically. Second, third and fourth generation Ph.D. students and postdoctoral associates are propagated outward from their advisors and labeled in the growing direction of the spiral. Close

generation of students and beyond. To illustrate this, an academic phylogeny of Ian Carmichael is depicted in Fig. 2. The figure shows his students, grand students, and some great-grand students as well as the colleagues and their academic progeny that he inspired and shepherded. To give some sense of the impact that Ian has made through his extraordinary mentoring, of the individuals academic associates of Ian are labeled in capital letters along with their Ph.D. students to differentiate them from Ian's direct advisory lineage. Concept and artwork by Véronique Robigou. A full scale (36 by 25 inches) high-resolution image of this figure may be downloaded from www.ofm-research.org/Carmichael/

listed in Fig. 2, nine have received the Bowen Award, two the Kuno Award, and three the Macelwane Medal from the American Geophysical Union, eight the Clarke or Goldschmidt Medal from the Geochemical Society, three the Dana Medal or MSA Award from the Mineralogical Society of America, three the Day Medal from the Geological Society of America, and there are 16 
Fellows of the Mineralogical Society of America, eight Fellows of the Geochemical Society, and 15 Fellows of the American Geophysical Union. Few great scientists can claim such a legacy, while at the same time having been equally honored for their own transformative research accomplishments in their discipline.

The papers included in this special issue were largely contributed by students and colleagues who knew Ian Carmichael well. They form a diverse selection of topics spanning theory, observation, and experiment. These papers parallel and reflect the breath of his own scientific interests. It is with honor and humility that we present this special issue of Contributions to Mineralogy and Petrology in the memory of a great petrologist and scientific mentor, whose contributions will continue to shape the lives of generations to come.

\section{Chronological bibliography of Ian S. E. Carmichael}

\section{0}

Carmichael, I.S.E., 1960. The pyroxenes and olivines from some Tertiary acid glasses. Journal of Petrology 1, 309-336.

\section{1}

Carmichael, I.S.E., McDonald, A., 1961. The colorimetric and polarographic determination of some trace elements in the standard rocks G-1 And W-1. Geochimica et Cosmochimica Acta 22, 87-93.

Carmichael, I.S.E., McDonald, A., 1961. The geochemistry of some natural acid glasses from the North Atlantic Tertiary Volcanic Province. Geochimica et Cosmochimica Acta 25, 189-222.

\section{2}

Carmichael, I.S.E., 1962. Pantelleritic liquids and their phenocrysts. Mineralogical Magazine 30, 86-113.

Stanton, R.E., McDonald, A.J., Carmichael, I.S.E., 1962. The determination of some trace elements in silicate rocks. Analyst 87, 134-139.

\section{3}

Carmichael, I.S.E., 1963. The crystallization of feldspar in volcanic acid liquids. Quarterly Journal of the Geological Society of London 119, 95-131.

Carmichael, I.S.E., MacKenzie, W.S., 1963. Feldsparliquid equilibria in pantellerites-An experimental study. American Journal of Science 261, 382-396.

\section{4}

Carmichael, I.S.E., 1964. The petrology of Thingmuli, a Tertiary volcano in Eastern Iceland. Journal of Petrology 5, 435-460.

Carmichael, I.S.E., 1964, Natural liquids and the phonolitic minimum. Geological Journal 4, 55-60.

Carmichael, I.S.E., MacKenzie, W.S., 1964. The lattice parameters of high-temperature triclinic sodic feldspars. Mineralogical Magazine 33, 949-962.

\section{5}

Carmichael, I.S.E., 1965. Trachytes and their feldspar phenocrysts. Mineralogical Magazine 34, 107-125.

\section{7}

Carmichael, I.S.E., 1967. The mineralogy of Thingmuli, a Tertiary volcano In Eastern Iceland. American Mineralogist 52, 1815-1841.

Carmichael, I.S.E., 1967. The iron-titanium oxides of salic volcanic rocks and their associated ferromagnesian silicates. Contributions to Mineralogy and Petrology 14, 36-64.

Carmichael, I.S.E., 1967. The mineralogy and petrology of the volcanic rocks from the Leucite Hills, Wyoming. Contributions to Mineralogy and Petrology 15, 24-66.

Carmichael, I.S.E., Nicholls, J., 1967. The iron-titanium oxides and oxygen fugacities in volcanic rocks. Journal of Geophysical Research-Solid Earth 72, 4665-4687.

Al-Rawi, Y., Carmichael, I.S.E., 1967. A note on the natural fusion of granite. American Mineralogist 52, 1806-1814.

\section{8}

Carmichael, I.S.E., Hampel, J., Jack, R.N., 1968. Analytical data on USGS standard rocks. Chemical Geology 3, 59-64.

Smith, A.L., Carmichael, I.S.E., 1968. Quaternary lavas from the Southern Cascades, Western U.S.A. Contributions to Mineralogy and Petrology 19, 212-238.

\section{9}

Carmichael, I.S.E., 1969. Crystallization paths of feldspathoidal lavas. Transactions-American Geophysical Union 50, 354.

Brown,F.H., Carmichael, I.S.E., 1969. Quaternary volcanoes of the Lake Rudolf region: I. The basanite-tephrite series of the Korath Range. Lithos 2, 239-260.

Jack, R.N., Carmichael, I.S.E., 1969. The chemical "fingerprinting" of acid volcanic rocks. California Division of 
Mines and Geology Short Contributions to California Geology, Special Report 100, 17-32.

Nash, W.P., Carmichael, I.S.E., Johnson, R.W., 1969. The mineralogy and petrology of Mount Suswa, Kenya. Journal of Petrology 10, 409-439.

Nicholls, J., Carmichael, I.S.E., 1969. A commentary on the absarokite-shoshonite-banakite series of Wyoming, U.S.A. Schweizer Mineralogische und Petrographische Mitteilungen 49, 47-64.

Smith, A.L., Carmichael, I.S.E., 1969. Quaternary trachybasalts from Southeastern California. American Mineralogist 54, 909-923.

\section{0}

Carmichael, I.S.E., Nicholls, J., Smith, A.L., 1970. Silica activity in igneous rocks. American Mineralogist 55, 246-263.

Lowder, G.G., Carmichael, I.S.E., 1970. Volcanoes and caldera of Talasea, New Britain. Geology and petrology. Geological Society of America Bulletin 81, 17-38.

Peterman, Z.E., Carmichael, I.S.E., Smith, A.L., 1970. $\mathrm{Sr}^{87} / \mathrm{Sr}^{86}$ ratios of Quaternary lavas of Cascade Range, Northern California. Geological Society of America Bulletin 81, 311-318.

Peterman, Z.E., Carmichael, I.S.E., Smith, A.L., 1970. Strontium isotopes In Quaternary basalts of Southeastern California. Earth Planetary Science Letters 7, 381-384.

Peterman, Z.E., Lowder, G.G., Carmichael, I.S.E., 1970. Sr ${ }^{87} /$ $\mathrm{Sr}^{86}$ Ratios of Talasea Series, New-Britain, Territory of NewGuinea. Geological Society of America Bulletin 81, 39-40.

Stormer, J.C., Carmichael, I.S.E., 1970. Kudo-Weill plagioclase geothermometer and porphyritic acid glasses. Contributions to Mineralogy and Petrology 28, 306-309. Stormer, J.C., Jr, Carmichael, I.S.E., 1970. Villiaumite and the occurrence of fluoride minerals in igneous rocks. American Mineralogist 55, 126-134.

\section{1}

Brown,F.H., Carmichael, I.S.E., 1971. Quaternary volcanoes of the Lake Rudolf region: II. The lavas of North Island, South Island, and the Barrier. Lithos 4, 305-323. Ewart, A., Green, D.C., Carmichael, I.S.E., Brown, F.H., 1971. Voluminous low temperature rhyolitic magmas In New Zealand. Contributions to Mineralogy and Petrology 33, 128-144. Nicholls, J., Carmichael, I.S.E., Stormer, J.C., 1971. Silica activity and $\mathrm{P}_{\text {total }}$ in igneous rocks. Contributions to Mineralogy and Petrology 33, 1-20.

Stormer, J.C., Carmichael, I.S.E., 1971. Fluorine-hydroxyl exchange in apatite and biotite: Potential igneous geothermometer. Contributions to Mineralogy and Petrology 31, 121-131.
Stormer, J.C., Carmichael, I.S.E., 1971. The free energy of sodalite and the behavior of chloride, fluoride and sulfate in silicate magmas. American Mineralogist 56, 292-306.

\section{2}

Nicholls, J., Carmichael, I.S.E., 1972. The equilibration temperature and pressure of various lava types with spineland garnet-peridotite. American Mineralogist 57, 941-959.

\section{3}

Bacon, C.R., Carmichael, I.S.E., 1973. Stages in $P-T$ path of ascending basalt magma: Example from San Quintin, Baja-California. Contributions to Mineralogy and Petrology 41, 1-22.

Bowles, F.A., Jack, R.N., Carmichael, I.S.E., 1973. Investigation of deep-sea volcanic ash layers from Equatorial Pacific cores. Geological Society of America Bulletin 84, 2371-2388.

Heming, R.F., Carmichael, I.S.E., 1973. High-Temperature pumice flows from Rabaul Caldera Papua, New Guinea. Contributions to Mineralogy and Petrology 38, 1-20.

Wood, B.J., Carmichael, I.S.E., 1973. $\mathrm{P}_{\text {total }}, \mathrm{P}_{\mathrm{H}_{2} \mathrm{O}}$ and the occurrence of cummingtonite in volcanic rocks. Contributions to Mineralogy and Petrology 40, 149-158.

\section{4}

Carmichael, I.S.E., Turner, F.J., Verhoogen, J., 1974. Igneous Petrology. McGraw-Hill, New York, 739 pp.

Marsh, B.D., Carmichael, I.S.E., 1974. Benioff zone magmatism. Journal of Geophysical Research-Solid Earth 79, 1196-1206.

\section{5}

Ewart, A., Hildreth, W., Carmichael, I.S.E., 1975. Quaternary acid magma In New Zealand. Contributions to Mineralogy and Petrology 51, 1-27.

\section{7}

Carmichael, I.S.E., Nicholls, J., Spera, F.J., Wood, B.J., Nelson, S.A., 1977. High-temperature properties of silicate liquids: Applications to the equilibration and ascent of basic magma. Philosophical Transactions of the Royal Society of London A 286, 373-431.

\section{8}

Beswick, A.E., Carmichael, I.S.E., 1978. Constraints on mantle source compositions imposed by phosphorus and 
rare-earth elements. Contributions to Mineralogy and Petrology 67, 317-330.

\section{9}

Carmichael, I.S.E., 1979. Glass and the glassy rocks, In, Yoder, H.S. Jr (editor), The Evolution of the Igneous Rocks. Fiftieth Anniversary Perspectives. Princeton University Press, Princeton, New Jersey, 233-244.

Ghiorso, M.S., Carmichael, I., Moret, L.K., 1979. Inverted high-temperature quartz: Unit-cell parameters and properties of the $\alpha-\beta$ Inversion. Contributions to Mineralogy and Petrology 68, 307-323.

Nelson, S.A., Carmichael, I.S.E., 1979. Partial molar volumes of oxide components in silicate liquids. Contributions to Mineralogy and Petrology 71, 117-124.

\section{0}

Beswick, A.E., Carmichael, I., 1980. Constraints on mantle source compositions imposed by phosphorus and the rareearth elements-Reply. Contributions to Mineralogy and Petrology 75, 175-178.

Ghiorso, M.S., Carmichael, I., 1980. Regular solution model for met-aluminous silicate liquids: Applications to geothermometry, immiscibility, and the source regions of basic magmas. Contributions to Mineralogy and Petrology 71, 323-342.

Luhr, J.F., Carmichael, I.S.E., 1980. Colima Volcanic Complex, Mexico. I. Post-caldera andesites from Volcán Colima. Contributions to Mineralogy and Petrology 71, 343-372.

Sack, R.O., Carmichael, I.S.E., Rivers, M., Ghiorso, M.S., 1980. Ferric-ferrous equilibria in natural silicate liquids at 1 bar. Contributions to Mineralogy and Petrology 75, 369-376.

Weill, D.F., Stebbins, J.F., Hon, R., Carmichael, I.S.E., 1980. The enthalpy of fusion of anorthite. Contributions to Mineralogy and Petrology 74, 95-102.

\section{1}

Baldridge, W.S., Carmichael, I.S.E., Albee, A.L., 1981. Crystallization paths of leucite-bearing lavas: Examples from Italy. Contributions to Mineralogy and Petrology 76, 321-335.

Ghiorso, M.S., Carmichael, I.S.E., 1981. A FORTRAN-IV computer program for evaluating temperatures and oxygen fugacities from the compositions of coexisting irontitanium oxides. Computers and Geosciences 7, 123-129.

Kyser, T.K., Oneil, J.R., Carmichael, I., 1981. Oxygen isotope thermometry of basic lavas and mantle nodules. Contributions to Mineralogy and Petrology 77, 11-23.
Luhr, J.F., Carmichael, I.S.E., 1981. The Colima Volcanic Complex, Mexico: Part II. Late-Quaternary Cinder Cones. Contributions to Mineralogy and Petrology 76, 127-147.

\section{2}

Kyser, T.K., Oneil, J.R., Carmichael, I., 1982. Genetic relations among basic lavas and ultramafic nodules: Evidence from oxygen isotope compositions. Contributions to Mineralogy and Petrology 81, 88-102.

Luhr, J.F., Carmichael, I.S.E., 1982. The Colima Volcanic Complex, Mexico: III. Ash- and scoria-fall deposits from the upper slopes of Volcán Colima. Contributions to Mineralogy and Petrology 80, 262-275.

Mo, X., Carmichael, I.S.E., Rivers, M., Stebbins, J.F., 1982. The partial molar volume of $\mathrm{Fe}_{2} \mathrm{O}_{3}$ in multicomponent silicate liquids and the pressure-dependence of oxygen fugacity in magmas. Mineralogical Magazine 45, 237-245.

Stebbins, J.F., Weill, D.F., Carmichael, I.S.E., Moret, L.K., 1982. High-temperature heat contents and heat-capacities of liquids and glasses in the system $\mathrm{NaAlSi}_{3} \mathrm{O}_{8}-\mathrm{CaAl}_{2-}$ $\mathrm{Si}_{2} \mathrm{O}_{8}$. Contributions to Mineralogy and Petrology $\mathbf{8 0}$, 276-284.

\section{3}

Ghiorso, M.S., Carmichael, I., Rivers, M.L., Sack, R.O., 1983. The Gibbs free energy of mixing of natural silicate liquids; An expanded regular solution approximation for the calculation of magmatic intensive variables. Contributions to Mineralogy and Petrology 84, 107-145.

Kilinc, A., Carmichael, I.S.E., Rivers, M.L., Sack, R.O., 1983. The ferric-ferrous ratio of natural silicate liquids equilibrated in air. Contributions to Mineralogy and Petrology 83, 136-140.

Stebbins, J.F., Carmichael, I.S.E., Weill, D.E., 1983. The high-temperature liquid and glass heat contents and the heats of fusion of diopside, albite, sanidine and nepheline. American Mineralogist 68, 717-730.

\section{4}

Allan, J.F., Carmichael, I.S.E., 1984. Lamprophyric lavas in the Colima Graben, SW Mexico. Contributions to Mineralogy and Petrology 88, 203-216.

Ghiorso, M.S., Carmichael, I., 1984. Density calculations for silicate liquids. 1. Revised method for aluminosilicate compositions-Comment. Geochimica et Cosmochimica Acta 48, 401-408.

Luhr, J.F., Carmichael, I.S.E., Varekamp, J.C., 1984. The 1982 eruptions of El Chichón Volcano, Chiapas, Mexico: Mineralogy and petrology of the anhydrite-bearing pumices. Journal of Volcanology and Geothermal Research 23, 69-108. 
Nelson, S.A., Carmichael, I.S.E., 1984. Pleistocene to recent alkalic volcanism in the region of Sanganguey Volcano, Nayarit, Mexico. Contributions to Mineralogy and Petrology 85, 321-335.

Sack, R.O., Carmichael, I.S.E., 1984. $\mathrm{Fe}^{2+} \Leftrightarrow \mathrm{Mg}^{2+}$ and $\mathrm{TiAl}_{2} \Leftrightarrow \mathrm{MgSi}_{2}$ exchange-reactions between clinopyroxenes and silicate melts. Contributions to Mineralogy and Petrology 85, 103-115.

Stebbins, J.F., Carmichael, I.S.E., 1984. The heat of fusion of fayalite. American Mineralogist 69, 292-297.

Stebbins, J.F., Carmichael, I.S.E., Moret, L.K., 1984. Heat capacities and entropies of silicate liquids and glasses. Contributions to Mineralogy and Petrology 86, 131-148.

\section{5}

Ghiorso, M.S., Carmichael, I., 1985. Chemical mass transfer in magmatic processes. II. Applications in equilibrium crystallization, fractionation and assimilation. Contributions to Mineralogy and Petrology 90, 121-141.

Hasenaka, T., Carmichael, I., 1985. The cinder cones of Michoacán-Guanajuato, Central Mexico: Their age, volume and distribution, and magma discharge rate. Journal of Volcanology and Geothermal Research 25, 105-124.

Luhr, J.F., Carmichael, I.S.E., 1985. Jorullo Volcano, Michoacán, Mexico (1759-1774): The earliest stages of fractionation in calc-alkaline magmas. Contributions to Mineralogy and Petrology 90, 142-161.

Luhr, J.F., Nelson, S.A., Allan, J.F., Carmichael, I.S.E., 1985. Active rifting in Southwestern Mexico: Manifestations of an incipient Eastward spreading-ridge jump. Geology 13, 54-57.

Mahood, G.A., Gilbert, C.M., Carmichael, I.S.E., 1985. Peralkaline and metaluminous mixed-liquid ignimbrites of the Guadalajara Region, Mexico. Journal of Volcanology and Geothermal Research 25, 259-271.

Murdoch, J.B., Stebbins, J.F., Carmichael, I.S.E., 1985. High-resolution $\mathrm{Si}^{29}$ NMR-study of silicate and aluminosilicate glasses: The effect of network-modifying cations. American Mineralogist 70, 332-343.

Mysen, B.O., Carmichael, I.S.E., Virgo, D., 1985. A comparison of iron redox ratios in silicate-glasses determined by wetchemical and $\mathrm{Fe}^{57}$ Mössbauer resonant absorption methods. Contributions to Mineralogy and Petrology 90, 101-106.

\section{6}

Carmichael, I., Ghiorso, M.S., 1986. Oxidation-reduction relations in basic magma: A case for homogeneous equilibria. Earth Planetary Science Letters 78, 200-210. Christie, D.M., Carmichael, I.S.E., Langmuir, C.H., 1986. Oxidation-states of mid-ocean ridge basalt glasses. Earth Planetary Science Letters 79, 397-411.
Kyser, T.K., Oneil, J.R., Carmichael, I.S.E., 1986. Possible non-equilibrium oxygen isotope effects in mantle nodules, An alternative to the Kyser-O'Neil-Carmichael $\mathrm{O}^{18}-\mathrm{O}^{16}$ geothermometer-Reply. Contributions to Mineralogy and Petrology 93, 120-123.

Lange, R.A., Carmichael, I.S.E., Stebbins, J.F., 1986. Phase-transitions in leucite $\left(\mathrm{KAlSi}_{2} \mathrm{O}_{6}\right)$, orthorhombic $\mathrm{KAlSiO}_{4}$, and their iron analogs $\left(\mathrm{KFeSi}_{2} \mathrm{O}_{6}, \mathrm{KFeSiO}_{4}\right)$. American Mineralogist 71, 937-945.

Stebbins, J.F., Murdoch, J.B., Carmichael, I.S.E., Pines, A., 1986. Defects and short-range order in nepheline group minerals: A $\mathrm{Si}^{29}$ Nuclear-Magnetic-Resonance study. Physics and Chemistry of Minerals 13, 371-381.

\section{7}

Ghiorso, M.S., Carmichael, I.S.E., 1987. Modeling magmatic systems-Petrologic applications. Reviews in Mineralogy and Geochemistry 17, 467-499.

Hasenaka, T., Carmichael, I.S.E., 1987. The cinder cones of Michoacan Guanajuato, Central Mexico-Petrology and chemistry. Journal of Petrology 28, 241-269.

Lange, R.A., Carmichael, I.S.E., 1987. Densities of $\mathrm{Na}_{2} \mathrm{O}-$ $\mathrm{K}_{2} \mathrm{O}-\mathrm{CaO}-\mathrm{MgO}-\mathrm{FeO}-\mathrm{Fe}_{2} \mathrm{O}_{3}-\mathrm{Al}_{2} \mathrm{O}_{3}-\mathrm{TiO}_{2}-\mathrm{SiO}_{2}$ liquids-New measurements and derived partial molar properties. Geochimica et Cosmochimica Acta 51, 2931-2946.

Mattioli, G.S., Wood, B.J., Carmichael, I.S.E., 1987. Ternary-spinel volumes in the system $\mathrm{MgAl}_{2} \mathrm{O}_{4}-\mathrm{Fe}_{3} \mathrm{O}_{4}-$ $\gamma \mathrm{Fe}_{8 / 3} \mathrm{O}_{4}$-Implications for the effect of $\mathrm{P}$ on intrinsic $\mathrm{fO}_{2}$ measurements of mantle-xenolith spinels. American Mineralogist 72, 468-480.

Rivers, M.L., Carmichael, I.S.E., 1987. Ultrasonic studies of silicate melts. Journal of Geophysical Research-Solid Earth 92, 9247-9270.

Sack, R.O., Walker, D., Carmichael, I.S.E., 1987. Experimental petrology of alkalic lavas-Constraints on cotectics of multiple saturation in natural basic liquids. Contributions to Mineralogy and Petrology 96, 1-23.

\section{8}

Kress, V.C., Carmichael, I.S.E., 1988. Stoichiometry of the iron oxidation reaction in silicate melts. American Mineralogist 73, 1267-1274.

Kress, V.C., Williams, Q., Carmichael, I., 1988. Ultrasonic investigation of melts in the system $\mathrm{Na}_{2} \mathrm{O}-\mathrm{Al}_{2} \mathrm{O}_{3}-\mathrm{SiO}_{2}$. Geochimica et Cosmochimica Acta 52, 283-293.

Murdoch, J.B., Stebbins, J.F., Carmichael, I.S.E., Pines, A., 1988. A Si ${ }^{29}$ Nuclear Magnetic-Resonance Study of silicon-aluminum ordering in leucite and analcite. Physics Chemistry of Minerals 15, 370-382. 


\section{9}

Carmichael, I.S.E., 1989. Presentation of the Mineralogical Society of America Award for 1988 to Jeanloz, Raymond. American Mineralogist 74, 719.

Kress, V.C., Carmichael, I.S.E., 1989. The lime-iron-silicate melt system-Redox and volume systematics. Geochimica et Cosmochimica Acta 53, 2883-2892.

Kress, V.C., Williams, Q., Carmichael, I., 1989. When is a silicate melt not a liquid? Geochimica et Cosmochimica Acta 53, 1687-1692.

Lange, R.A., Carmichael, I.S.E., 1989. Ferric-ferrous equilibria in $\mathrm{Na}_{2} \mathrm{O}-\mathrm{FeO}-\mathrm{Fe}_{2} \mathrm{O}_{3}-\mathrm{SiO}_{2}$ melts-Effects of analytical techniques on derived partial molar volumes. Geochimica et Cosmochimica Acta 53, 2195-2204.

Luhr, J.F., Allan, J.F., Carmichael, I.S.E., Nelson, S.A., Hasenaka, T., 1989. Primitive calc-alkaline and alkaline rock types from the Western Mexican Volcanic Belt. Journal of Geophysical Research Solid Earth 94, 4515-4530.

Wallace, P.J., Carmichael, I.S.E., 1989. Minette lavas and associated leucitites from the Western Front of The Mexican Volcanic Belt-Petrology, chemistry, and origin. Contributions to Mineralogy and Petrology 103, 470-492.

\section{0}

Carmichael, I.S.E., Ghiorso, M.S., 1990. The effect of oxygen fugacity on the redox state of natural liquids and their crystallizing phases. Reviews in Mineralogy and Geochemistry 24, 191-212.

Lange, R.A., Carmichael, I.S.E., 1990. Hydrous basaltic andesites associated with minette and related lavas in Western Mexico. Journal of Petrology 31, 1225-1259.

Lange, R.L., Carmichael, I.S.E., 1990. Thermodynamic properties of silicate liquids with emphasis on density, thermal-expansion and compressibility. Reviews in Mineralogy and Geochemistry 24, 25-64.

Luhr, J.F., Carmichael, I.S.E., 1990. Petrological monitoring of cyclical eruptive activity at Volcán Colima, Mexico. Journal of Volcanology and Geothermal Research 42, 235-260.

\section{1}

Carmichael, I.S.E., 1991. The redox states of basic and silicic magmas-A reflection of their source regions. Contributions to Mineralogy and Petrology 106, 129141.

Kress, V.C., Carmichael, I.S.E., 1991. The compressibility of silicate liquids containing $\mathrm{Fe}_{2} \mathrm{O}_{3}$ and the effect of composition, temperature, oxygen fugacity and pressure on their redox states. Contributions to Mineralogy and Petrology 108, 82-92.

Lange, R.A., Carmichael, I.S.E., 1991. A potassic volcanic front in Western Mexico-The lamprophyric and related lavas of San Sebastian. Geological Society of America Bulletin 103, 928-940.

Allan, J.F., Nelson, S.A., Luhr, J.F., Carmichael, I.S.E., Wopat, M., Wallace, P. (1991) Pliocene-Holocene rifting and associated volcanism in SW Mexico: an exotic terrain in the making. In: Dauphin, J.P., Simoneit, B.R.T. (eds) The Gulf and Peninsular Province of the Californias. AAPG Memoir 47, 425-445.

\section{2}

Righter, K., Carmichael, I.S.E., 1992. Hawaiites and related lavas in the Atenguillo graben, Western Mexican Volcanic Belt. Geological Society of America Bulletin 104, 1592-1607.

Snyder, D.A., Carmichael, I.S.E., 1992. Olivine-liquid equilibria and the chemical activities of $\mathrm{FeO}, \mathrm{NiO}, \mathrm{Fe}_{2} \mathrm{O}_{3}$, and $\mathrm{MgO}$ in natural basic melts. Geochimica et Cosmochimica Acta 56, 303-318.

Wallace, P.J., Carmichael, I.S.E., 1992. Sulfur in basaltic magmas. Geochimica et Cosmochimica Acta 56, 1863-1874.

Wallace, P.J., Carmichael, I.S.E., 1992. Alkaline and calcalkaline lavas near Los-Volcanes, Jalisco, Mexico-Geochemical diversity and its significance in volcanic arcs. Contributions to Mineralogy and Petrology 111, 423-439.

Wallace, P.J., Carmichael, I.S.E., Righter, K., Becker, T.A., 1992. Volcanism and tectonism in Western Mexico-A contrast of style and substance. Geology $\mathbf{2 0}$, 625-628.

\section{3}

Lange, R.A., Carmichael, I.S.E., Renne, P.R., 1993. Potassic volcanism near Mono Basin, California-Evidence for high water and oxygen fugacities inherited from subduction. Geology 21, 949-952.

Righter, K., Carmichael, I.S.E., 1993. Mega-xenocrysts in alkali olivine basalts-Fragments of disrupted mantle assemblages. American Mineralogist 78, 1230-1245.

Snyder, D., Carmichael, I.S.E., Wiebe, R.A., 1993. Experimental-study of liquid evolution in an Fe-Rich, layered mafic intrusion-Constraints of $\mathrm{Fe}-\mathrm{Ti}$ oxide precipitation on the $\mathrm{T}-\mathrm{fO}_{2}$ and $\mathrm{T}-\rho$ paths of tholeiitic magmas. Contributions to Mineralogy and Petrology 113, 73-86.

\section{4}

Moore, G., Marone, C., Carmichael, I.S.E., Renne, P., 1994. Basaltic volcanism and extension near the 
intersection of the Sierra Madre volcanic province and the Mexican Volcanic Belt. Geological Society of America Bulletin 106, 383-394.

Snyder, D., Gier, E., Carmichael, I.S.E., 1994. Experimental determination of the thermal-conductivity of molten $\mathrm{CaMgSi}_{2} \mathrm{O}_{6}$ and the transport of heat through magmas. Journal of Geophysical Research-Solid Earth 99, 15503-15516.

Snyder, D.A., Carmichael, I.S.E., 1994. Olivine-liquid equilibria and the chemical activities of $\mathrm{FeO}, \mathrm{NiO}, \mathrm{Fe}_{2} \mathrm{O}_{3}$, and $\mathrm{MgO}$ in natural basic melts, (errata for 56, 303-318, 1992). Geochimica et Cosmochimica Acta 58, 1044.

Wallace, P.J., Carmichael, I.S.E., 1994. S-speciation in submarine basaltic glasses as determined by measurements of $\mathrm{S} \mathrm{K} \alpha \mathrm{X}$-Ray Wavelength Shifts. American Mineralogist 79, 161-167.

Wallace, P.J., Carmichael, I.S.E., 1994. Petrology of Volcán Tequila, Jalisco, Mexico-disequilibrium phenocryst assemblages and evolution of the subvolcanic magma system. Contributions to Mineralogy and Petrology 117, 345-361.

\section{5}

Carmichael, I.S.E., 1995. Introduction of Lange, Rebecca, A. for the $1995 \mathrm{~F} \mathrm{~W}$ Clarke Award. Geochimica et Cosmochimica Acta 59, 4569-4570.

Moore, G., Righter, K., Carmichael, I.S.E., 1995. The effect of dissolved water on the oxidation-state of iron in natural silicate liquids. Contributions to Mineralogy and Petrology 120, 170-179.

Moore, G., Vennemann, T., Carmichael, I.S.E., 1995. Solubility of water in magmas to 2 kbar. Geology 23, 1099-1102.

Righter, K., Carmichael, I.S.E., Becker, T.A., Renne, P.R., 1995. Pliocene-Quaternary volcanism and faulting at the intersection of the Gulf of California and the Mexican Volcanic Belt. Geological Society of America Bulletin 107, 612-626.

Snyder, D., Gier, E., Carmichael, I.S.E., 1995. Experimental determination of the thermal-conductivity of molten $\mathrm{CaMgSi}_{2} \mathrm{O}_{6}$ and the transport of heat through magmas-Reply. Journal of Geophysical Research-Solid Earth 100, 22403-22405.

\section{6}

Carmichael, I.S.E., Lange, R.A., Luhr, J.F., 1996. Quaternary minettes and associated volcanic rocks of Mascota, western Mexico: A consequence of plate extension above a subduction modified mantle wedge. Contributions to Mineralogy and Petrology 124, 302-333.
Gier, E.J., Carmichael, I.S.E., 1996. Thermal conductivity of molten $\mathrm{Na}_{2} \mathrm{SiO}_{3}$ and $\mathrm{CaNa}_{4} \mathrm{Si}_{3} \mathrm{O}_{9}$. Geochimica et Cosmochimica Acta 60, 355-357.

Lange, R.A., Carmichael, I.S.E., 1996. The Aurora volcanic field, California-Nevada: Oxygen fugacity constraints on the development of andesitic magma. Contributions to Mineralogy and Petrology 125, 167-185.

Righter, K., Carmichael, I.S.E., 1996. Phase equilibria of phlogopite lamprophyres from western Mexico: Biotite-liquid equilibria and P-T estimates for biotite-bearing igneous rocks. Contributions to Mineralogy and Petrology 123, 1-21.

\section{7}

Melbourne, T., Carmichael, I.S.E., DeMets, C., Hudnut, K., Sanchez, O., Stock, J., Suarez, G., Webb, F., 1997. The geodetic signature of the M8.0 October 9, 1995, Jalisco subduction earthquake. Geophysical Research Letters 24, 715-718.

Snyder, D., Gier, E., Carmichael, I., 1997. Experimental determination of the thermal conductivity of molten $\mathrm{CaMgSi}_{2} \mathrm{O}_{6}$ and the transport of heat through magmas-Reply. Journal of Geophysical Research-Solid Earth 102, 15077-15080.

\section{8}

Blatter, D.L., Carmichael, I., 1998. Plagioclase-free andesites from Ziticuaro (Michoacan), Mexico: petrology and experimental constraints. Contributions to Mineralogy and Petrology 132, 121-138.

Blatter, D.L., Carmichael, I., 1998. Hornblende peridotite xenoliths from central Mexico reveal the highly oxidized nature of sub-arc upper mantle. Geology 26, 1035-1038.

Carmichael, I.S.E., 1998. Acceptance of the Roebling medal of the Mineralogical Society of America for 1997. American Mineralogist 83, 914-915.

Moore, G., Carmichael, I., 1998. The hydrous phase equilibria (to $3 \mathrm{kbar}$ ) of an andesite and basaltic andesite from western Mexico: constraints on water content and conditions of phenocryst growth. Contributions to Mineralogy and Petrology 130, 304-319.

Moore, G., Vennemann, T., Carmichael, I.S.E., 1998. An empirical model for the solubility of $\mathrm{H}_{2} \mathrm{O}$ in magmas to 3 kilobars. American Mineralogist 83, 36-42.

\section{9}

Wallace, P.J., Carmichael, I.S.E., 1999. Quaternary volcanism near the Valley of Mexico: Implications for subduction zone magmatism and the effects of crustal thickness variations on primitive magma compositions. Contributions to Mineralogy and Petrology 135, 291-314. 


\section{0}

Lange, R.A., Carmichael, I.S.E., Hall, C.M., 2000. $\mathrm{Ar}^{40} /$ $\mathrm{Ar}^{39}$ chronology of the Leucite Hills, Wyoming: eruption rates, erosion rates, and an evolving temperature structure of the underlying mantle. Earth Planetary Science Letters 174, 329-340.

Lange, R.A., Carmichael, I.S.E., Hall, C.M., 2000. $\mathrm{Ar}^{40} /$ $\mathrm{Ar}^{39}$ chronology of the Leucite Hills, Wyoming: eruption rates, erosion rates, and an evolving temperature structure of the underlying mantle (errata for 174, 329-340, 2000). Earth Planetary Science Letters 178, 427.

\section{1}

Blatter, D.L., Carmichael, I., 2001. Hydrous phase equilibria of a Mexican high-silica andesite: A candidate for a mantle origin? Geochimica et Cosmochimica Acta 65, 4043-4065.

Blatter, D.L., Carmichael, I., Deino, A.L., Renne, P.R., 2001. Neogene volcanism at the front of the central Mexican volcanic belt: Basaltic andesites to dacites, with contemporaneous shoshonites and high- $\mathrm{TiO}_{2}$ lava. Geological Society of America Bulletin 113, 1324-1342.

\section{2}

Carmichael, I.S.E., 2002. The andesite aqueduct: perspectives on the evolution of intermediate magmatism in west-central $\left(105-99^{\circ} \mathrm{W}\right)$ Mexico. Contributions to Mineralogy and Petrology 143, 641-663.

Wood, B.J., Carmichael, I.S.E., 2002. Professor W. S. MacKenzie, 1920-2001-Obituary. Mineralogical Magazine 66, 465-466.

\section{3}

Blatter, D.L., Carmichael, I., Deino, A.L., Renne, P., 2003. Discussion and reply: Neogene volcanism at the front of the central Mexican Volcanic Belt: Basaltic andesites to dacites, with contemporaneous shoshonites and high- $\mathrm{TiO}_{2}$ lavaReply. Geological Society of America 115, 1021-1024.

\section{4}

Barclay, J., Carmichael, I.S.E., 2004. A hornblende basalt from western Mexico: Water-saturated phase relations constrain a pressure-temperature window of eruptibility. Journal of Petrology 45, 485-506.

Carmichael, I.S.E., 2004. Presentation of the Mineralogical Society of America Dana Medal for 2003 to Mark S. Ghiorso. American Mineralogist 89, 909.

Carmichael, I.S.E., 2004. The activity of silica, water, and the equilibration of intermediate and silicic magmas. American Mineralogist 89, 1438-1446.

Carmichael, I.S.E. (editor), 2004. Landmark Papers in Volcanic Petrology. Mineralogical Society of Great Britain and Ireland, $319 \mathrm{pp}$.

\section{6}

Carmichael, I.S.E., Frey, H.M., Lange, R.A., Hall, C.M., 2006. The Pleistocene cinder cones surrounding Volcán Colima, Mexico re-visited: eruption ages and volumes, oxidation states, and sulfur content. Bulletin of Volcanology 68, 407-419.

Carmichael, I.S.E., Lange, R.A., Hall, C.M., Renne, P.R., 2006. Faulted and tilted Pliocene olivine tholeiite lavas near Alturas, NE California, and their bearing on the uplift of the Warner Range. Geological Society of America Bulletin 118, 1196-1211.

\section{7}

Blatter, D.L., Farmer, G.L., Carmichael, I.S.E., 2007. A north-south transect across the central Mexican volcanic belt at $\sim 100^{\circ} \mathrm{W}$ : Spatial distribution, petrological, geochemical, and isotopic characteristics of quaternary volcanism. Journal of Petrology 48, 901-950.

Frey, H.M., Lange, R.A., Hall, C.M., Delgado-Granados, H., Carmichael, I.S.E., 2007. A Pliocene ignimbrite flareup along the Tepic-Zacoalco rift: Evidence for the initial stages of rifting between the Jalisco block (Mexico) and North America. Geological Society of America Bulletin 119, 49-64. 